\title{
Accessory mitral valve tissue causing left ventricular outflow tract obstruction
}

\author{
W G MELDRUM-HANNA, T B CARTMILL, RE HAWKER, J M CELERMAJER, \\ C M WRIGHT
}

From the Basser Institute of Cardiology, Royal Alexandra Hospital for Children, Camperdown, New South Wales, Australia

SUMMARY Although left ventricular outflow tract obstruction is commonly associated with congenitally corrected transposition of the great vessels, this obstruction is seldom caused by accessory mitral valve tissue. Three cases in which accessory mitral valve tissue caused left ventricular outflow tract obstruction in children are described. Two had congenitally corrected transposition and one had normally connected great vessels. The accessory leaflet tissue, which was identified by echocardiography and angiography, was attached by chordae tendineae to normally sited papillary muscles and herniated into the left ventricular outflow tract during systole.

Operation was successful in these patients. The accessory valve tissue was excised via an arteriotomy in the great vessel that arose from the left ventricle. The obstructive tissue was excised close to its peripheral attachments in the outflow tract and its chordae tendineae were divided. Resection was performed without injury to the abnormally placed conduction system or to the normal valve structures.

In congenitally corrected transposition the outflow of the right sided morphologically left ventricle to the pulmonary artery is obstructed in $33 \%$ to $50 \%$ of cases. This obstruction may be at the level of the pulmonary valve but is more commonly subvalvar.

Requests for reprints to Mr W G Meldrum-Hanna, FRACS, 4 Telopea Street, Wollstonecraft, NSW 2065, Australia.

Accepted for publication 26 November 1985
Also in about $80 \%$ of all cases of corrected transposition with pulmonary stenosis a ventricular septal defect is present, and in a third of these cases there are morphological tricuspid valve anomalies. ${ }^{1-3}$

We report three patients with accessory mitral valve tissue which caused left ventricular outflow tract obstruction in two children with congenitally corrected transposition and in one child with normally connected great vessels.

Table Accessory mitral valve tissue causing left ventricular outflow tract obstruction

\begin{tabular}{|c|c|c|c|c|c|c|}
\hline Patient & Sex & $\begin{array}{l}\text { Age } \\
(y r)\end{array}$ & Pathology & $\begin{array}{l}\text { Pressure } \\
\text { gradient } \\
\text { in the out- } \\
\text { flow tract of } \\
\text { the morpho- } \\
\text { logical left } \\
\text { ventricle } \\
\text { ( } \mathrm{mm} \mathrm{Hg} \text { ) }\end{array}$ & Operation & Result \\
\hline 1 & $\mathbf{M}$ & 8 & $\begin{array}{l}\text { Congenitally corrected } \\
\text { transposition, pulmonary } \\
\text { stenosis, accessory MV tissue }\end{array}$ & 112 & $\begin{array}{l}\text { Pulmonary valvotomy and } \\
\text { resection of accessory MV } \\
\text { tissue via MPA }\end{array}$ & $\begin{array}{l}\text { Well, residual } \\
\text { gradient of } \\
40 \mathrm{~mm} \mathrm{Hg}\end{array}$ \\
\hline 2 & $\mathbf{M}$ & 15 & $\begin{array}{l}\text { Congenitally corrected } \\
\text { transposition, accessory } \\
\text { MV tissue }\end{array}$ & 103 & $\begin{array}{l}\text { Resection of accessory } \\
\text { MV tissue }\end{array}$ & Well \\
\hline 3 & $\mathrm{~F}$ & 7 & $\begin{array}{l}\text { Accessory MV tissue, muscular } \\
\text { subaortic stenosis }\end{array}$ & 80 & $\begin{array}{l}\text { Resection accessory } \\
\text { MV tissue, limited } \\
\text { myomectomy }\end{array}$ & $\begin{array}{l}\text { Re-do } \\
\text { myomectomy } \\
\text { for SAS, two } \\
\text { years after } \\
\text { operation }\end{array}$ \\
\hline
\end{tabular}



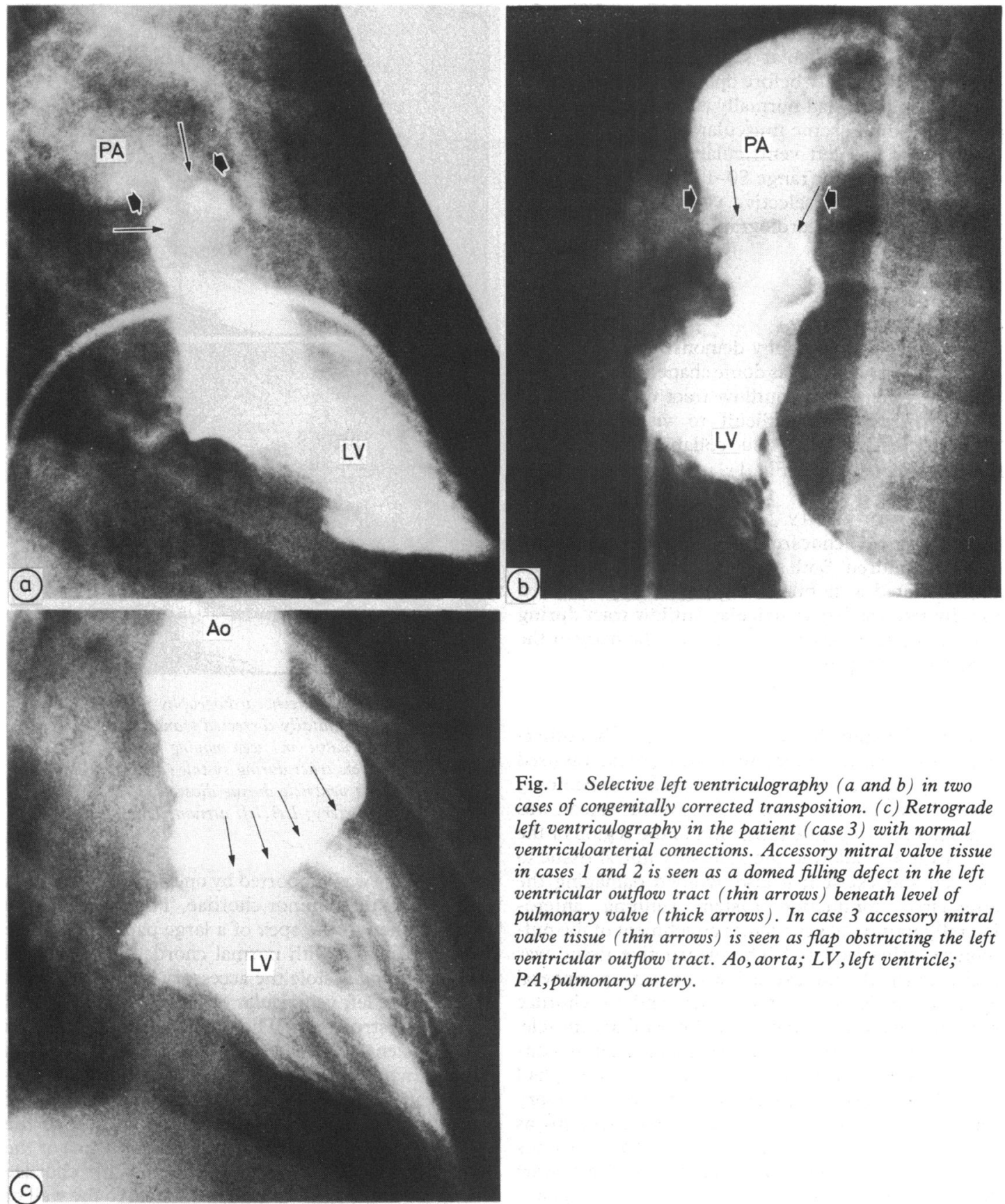

Fig. 1 Selective left ventriculography ( $a$ and $b$ ) in two cases of congenitally corrected transposition. (c) Retrograde left ventriculography in the patient (case 3 ) with normal ventriculoarterial connections. Accessory mitral valve tissue in cases 1 and 2 is seen as a domed filling defect in the left ventricular outflow tract (thin arrows) beneath level of pulmonary valve (thick arrows). In case 3 accessory mitral valve tissue (thin arrows) is seen as flap obstructing the left ventricular outflow tract. Ao, aorta; $L V$, left ventricle; $P A$, pulmonary artery.

\section{Patients and methods}

Between 1980 and 1984 three children (aged 6-15 years) presented at this hospital for investigation of left ventricular outflow tract obstruction (Table). Two children (cases 2 and 3) had dyspnoeic grade I New York Heart Association class heart disease. The other child was symptom free but presented with a 
murmur. Two children (cases 1 and 2) had congenitally corrected transposition; one of them (case 2) also had a ventricular septal defect which had closed spontaneously before operation. The remaining child (case 3 ) had normally connected great vessels but also had some muscular subaortic stenosis. All patients had left ventricular outflow tract gradients $>80 \mathrm{~mm} \mathrm{Hg}$ (range $80-112 \mathrm{~mm} \mathrm{Hg}$ ).

All patients had selective ventriculography and cross sectional echocardiography.

\section{Results}

\section{VENTRICULOGRAPHY}

Selective ventriculography demonstrated the accessory mitral valve tissue as dome shaped filling defects in the left ventricular outflow tract during systole. These defects were difficult to visualise during diastole when the valve tissue collapsed back into the body of the ventricle (Fig. 1).

\section{ECHOCARDIOGRAPHY}

Cross sectional echocardiography was performed in all three children. Both short axis and long axis views demonstrated a mobile filling defect which moved rapidly into the left ventricular outflow tract during systole and then prolapsed back into the body of the ventricle during diastole (Fig. 2a and $b$ ).

\section{OPERATION}

Cardiopulmonary bypass with moderate hypother$\mathrm{mia}\left(25^{\circ} \mathrm{C}\right)$ and cold potassium cardioplegia was used routinely. After transverse pulmonary arteriotomy (cases 1 and 2), the valvar and subvalvar region was examined. Very gentle retraction in the region of the subvalvar area allowed the accessory mitral tissue to be seen and excised; it also avoided damaging the attenuated conduction system running anterolaterally round the ventricular attachment of the pulmonary valve leaflets. ${ }^{4}$ The obstructive tissue was easily grasped and excised around its peripheral attachments in the outflow tract, and its chordae tendineae were divided close to the papillary muscle.

The child with normal ventriculoarterial connections and subaortic muscular stenosis (case 3 ) had an oblique aortotomy, excision of the accessory mitral valve tissue, and a limited septal myotomy as well. All patients were weaned from bypass in sinus rhythm. There have been no instances of late heart block during a follow up of from two to five years.

\section{OPERATIVE PATHOLOGY}

The accessory mitral valve tissue (Fig. 3) was excised in each case. Typically (cases 1 and 2) the tissue took the form of an accessory dome shaped leaflet attached partly to the right rim of the outflow tract.

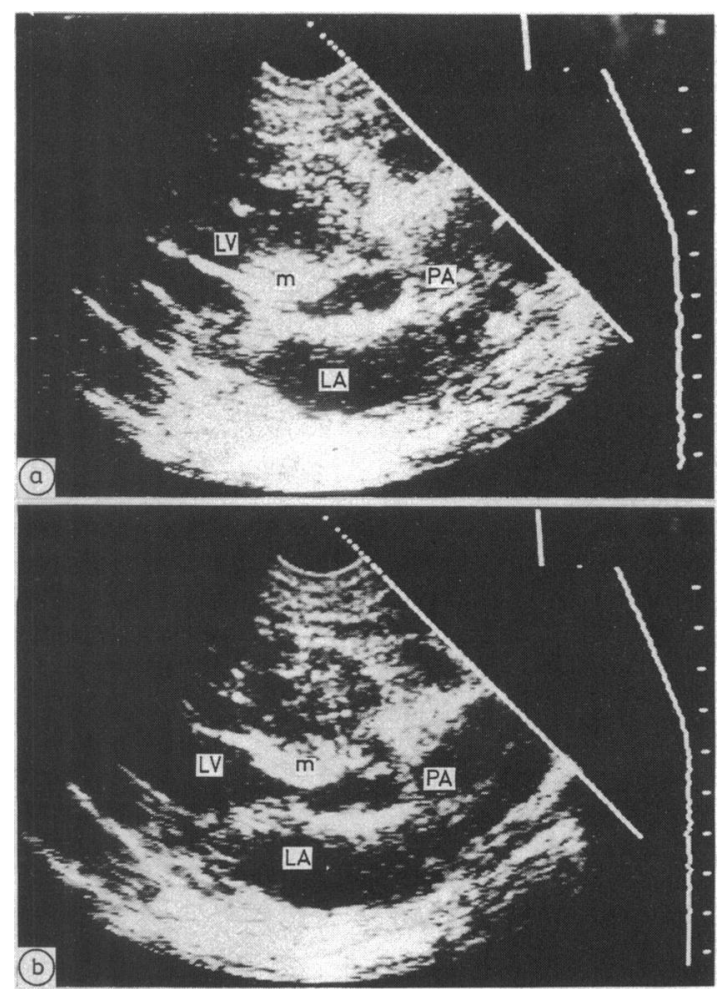

Fig. 2 Cross sectional echocardiography in long axis view in case 1 with congenitally corrected transposition. Accessory mitral valve ( $m$ ) seen moving into left ventricular outflow tract during systole (a) and prolapsing back into the left ventricle during diastole $(b)$.

$P A$, pulmonary artery; $L A$, left atrium; $L V$, morphological left ventricle.

Its free edge was supported by one prominent chorda and two or three minor chordae. The major chorda was attached to the apex of a large papillary muscle which it shared with normal chordae of the mitral valve. During systole the accessory leaflet ballooned out into the left ventricular outflow tract and caused severe obstruction. The pulmonary valve was slightly stenosed in case 1 . In case 3 , the patient with the normal ventriculoarterial connection, the accessory leaflet was attached around the leftward part of the anterior mitral valve leaflet and ran on to the septum for about a third of the circumference of the outflow tract. There were also some short chordae along the free edge attaching the leaflet to the wall of the outflow tract.

\section{Discussion}

Anomalies of the mitral valve causing simple left ventricular outflow tract obstruction are uncommon, 

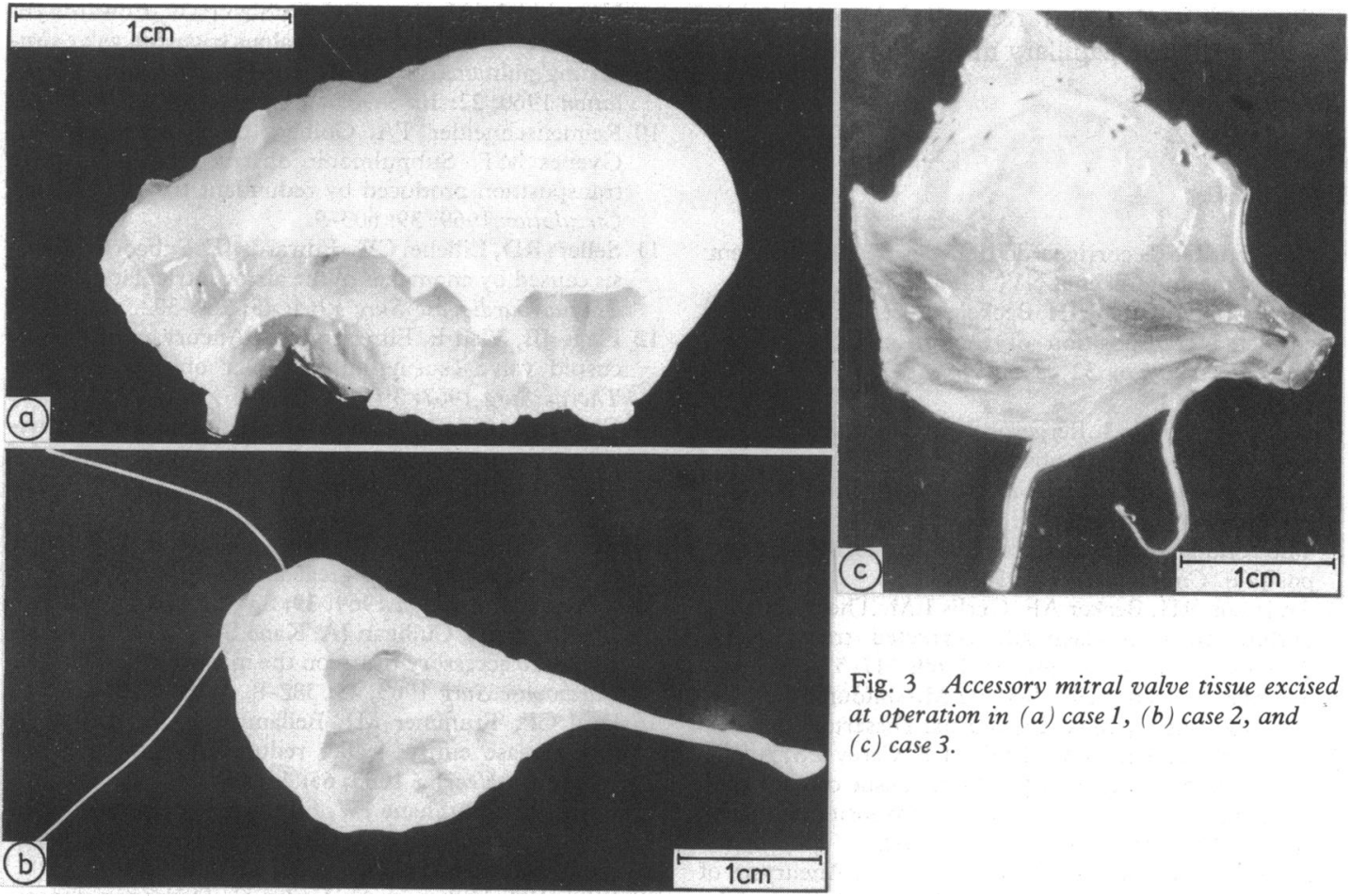

Fig. 3 Accessory mitral valve tissue excised at operation in (a) case 1, (b) case 2, and (c) case 3 .

but atrioventricular valve anomalies are frequently $(20 \%)$ seen in cases of congenitally corrected transposition. ${ }^{125}$ These are usually "aneurysmal" dilatations of fibrous tissue in the region of the left ventricular outflow tract. This tissue was described initially as originating from the morphological mitral valve by Tonnies in $1884 . .^{6}$ Levy et al in 1963 described three necropsy specimens from patients with congenitally corrected transposition in which two had "umbrella" like formations of accessory valvar tissue protruding into the subpulmonary area. ${ }^{7}$ This tissue was attached by chordae-like strands to pulmonary and atrioventricular tissue and to the superior edges of the ventricular septal defect. The accessory tissue obstructed both the ventricular septal defect and the subpulmonary region. Another patient, without ventricular septal defect, had valve tissue, without chordae, attached to the ventricular aspect of the atrioventricular valve.

Aneurysmal tissue tags arise more commonly from bulging of the interventricular septum (membranous component $)^{8}$ or from redundant tricuspid valve tissue herniating through a ventricular septal defect ${ }^{9-14}$ and less commonly from the pulmonary valve itself.

Abnormalities of the mitral valve causing left ventricular outflow tract obstruction are less common. ${ }^{14}$
MacLean et al reported subaortic stenosis caused by accessory tissue on the mitral valve which formed two cup-shaped "diverticula" on the ventricular surface of the anterior leaflet of a patient presenting with dextrocardia. ${ }^{15}$ Deal et al reported another case in which there were slit-like fenestrations of an aneurysmal bulging accessory leaflet which were thought to represent an attempt at reduplication of the mitral valve. ${ }^{16}$ Both sets of workers noted that it was difficult to identify the tissue at operation. The diagnosis was not made before operation because left heart catheterisation had not been performed. Subaortic stenosis has also been reported with abnormal attachment of the anterior leaflet of the mitral valve, either directly to the interventricular septum or via abnormal chordae to the septum. ${ }^{1718}$

The three children we have described in this paper all had accessory mitral valve leaflet tissue that almost duplicated the anterior leaflet. This tissue was continuous with the left ventricular outflow tract valve annulus and was attached by its own chordae to otherwise normally sited papillary muscles.

Successful operation was relatively simple. We approached the accessory tissue via the pulmonary artery (or aorta) and took care not to damage the conduction system. The accessory leaflet tissue was excised close to its attachment to the base of the 
outflow tract valve and redundant chordae were divided near their papillary muscle insertion.

\section{References}

1 Losekoot G. Gecorrigeerde transposities. Amsterdam: Scheltema en Holkema NV, 1967. Thesis.

2 Allwork SP, Bentall HH, Becker AE, et al. Congenitally corrected transposition of the great arteries: morphologic study of 32 cases. Am $\mathcal{F}$ Cardiol 1976; 38: 910-23.

3 Sansa M, Tonkin I, Bergeron LM, Elliott L. Left ventricular outflow tract obstructions in transposition of the great arteries. Am f Cardiol 1979; 44: 88-95.

4 Anderson RH, Becker AE, Arnold R, Wilkinson JL. The conduction tissue in congenitally corrected transposition. Circulation 1974; 50: 911-24.

5 Anderson RH, Becker AE, Gerlis LM. The pulmonary outflow tract in classically corrected transposition. f Thorac Cardiovasc Surg 1975; 69: 747-57.

6 Tonnies A. Ueber eine Seltene Missbildung des Herzens. Gottingen, 1884. Inaugurual Dissertation.

7 Levy ML, Lillehei CW, Elliott LP, Carey LS, Adams $\mathrm{P}$, Edwards JE. Accessory valvular tissue causing subpulmonary stenosis in corrected transposition of great vessels. Circulation 1963; 27: 492-502.

8 Summerall CP, Clowes GH, Boone TA. Aneurysm of ventricular septal defect with outflow obstruction of the venous ventricle in corrected transposition of great vessels. Am Heart f 1966; 72: 525-9.
9 Neufeld HN, McGoon DC, DuShane JW, Edwards JE. Tetralogy of Fallot with anomalous tricuspid valve simulating pulmonary stenosis with intact septum. Circulation 1960; 22: 1083-90.

10 Reimenschneider TA, Golberg SJ, Ruttenberg HD, Gyepes MT. Subpulmonic obstruction in complete transposition produced by redundant tricuspid tissue. Circulation 1969; 39: 603-9.

11 Sellers RD, Lillehei CW, Edwards JE. Subaortic stenosis caused by anomalies of the atrioventricular valves. $\mathcal{F}$ Thorac Cardiovasc Surg 1964; 48: 289-302.

12 Flege JB, Vlad P, Ehrenhaft JL. Aneurysm of the tricuspid valve causing infundibular obstruction. Ann Thorac Surg 1967; 3: 446-8.

13 Chesler E, Korne NE, Edwards JE. Anomalies of tricuspid valve including pouches resembling aneurysm of the membranous ventricular septum. Am $\mathcal{F}$ Cardiol 1968; 21: 661-8.

14 Rastelli GC, Wallace RB, Ongley PA. Complete repair of transposition of the great arteries with pulmonary stenosis. Circulation 1969; 39: 83-95.

15 MacLean LD, Culligan JA, Kane DJ. Subaortic stenosis due to accessory tissue on the mitral valve. $f$ Thorac Cardiovasc Surg 1963; 45: 382-8.

16 Deal CP, Trummer MJ, Bellamy JC, Timmes JJ. A new disease entity: leaflet redundancy of the mitral valve. Am Heart $\mathcal{F}$ 1963; 65: 441-5.

17 Lauer RM, DuShane JW, Edwards JE. Obstruction of left ventricular outlet in association with ventricular septal defect. Circulation 1960; 22: 110-25.

18 Björk VO, Hultquist G, Lodin H. Subaortic stenosis produced by an abnormally placed anterior mitral leaflet. I Thorac Surg 1961; 41: 659-69. 